\title{
Penentukan Indeks Bias Lapisan Tipis dengan menggunakan Ellipsometer
}

\author{
Satwiko $\mathrm{S}^{*}$ \\ Jurusan Fisika, Universitas Negeri Jakarta \\ Rawamangum Muka, Jakarta 13220
}

\begin{abstract}
Intisari
Penelitian amorphous silicon film tipis yang pelapisnya dilakukan di atas bahan semi transparan dan non transparan. Dengan menggunakan Ellipsometer menghasilkan pengukuran yang sangat akurat, dan dengan menggunakan komputer program hasil percobaan diolah serta dibandingkan antara pengukuran dilakukan sebelumnya.
\end{abstract}

KATA KUNCI: lapisan tipis, indeks bias, ellipsometer

\section{PENDAHULUAN}

Sel photovoltaic (PV) menjadi populer sebagai energi alternatif, beberapa alasan lainya antara lain: (a). mempunyai harapan bertahan hidup lebih dari 20 tahunan, (b). mempunyai sedikit atau bahkan tidak ada dampak lingkungannya,(c). tidak membutuhkan jaringan distribusi.

Alasan-alasan inilah yang membuat sel photovoltaik menjadi lebih efisien dan efektif dibandingkan dengan minyak, lebih lanjut PV telah memperoleh perhatian yang lebih besar untuk memimpin pasar. Faktor yang paling penting dalam pengembangan sel surya adalah untuk memaksimalkan keefektifan biaya, ini adalah pertukaran antara harga material dan efisiensi material dalam merubah cahaya matahari menjadi listrik. Dengan menggunakan materi-materi yang tidak mahal, efisiensi yang lebih rendah mungkin bisa bersaing dengan efisiensi tinggi tapi dengan kristal solar sel yang mahal.

Masalah ekonomi ini yang merangsang ilmuan untuk mencoba membuat solar sel dengan materi yang murah dan memiliki efisiensi tinggi.

Generasi pertama PV dibuat dari kristal tunggal silikon tapi dengan harga silikon yang sangat mahal, oleh karena itu perkembangan materi baru, silikon amorf menjadikan yang menjanjikan. Zat padat amorf adalah materi yang cacat dan mengandung banyak kerusakan struktur. Pada kristal silikon tunggal, satu atom silikon terikat dengan 4 atom silicon lainnya, sementara pada silikon amorf yang mempunyai banyak kerusakan, satu atom mungkin terikat dengan satu, dua, tiga atau empat atom silikon lainnya. Materi silikon amorf mempunyai potensi untuk menjadi sumber energi matahari karena beberapa keuntungan, antara lain silikon amorf hanya membutuhkan film kira-kira $1 \mu \mathrm{m}$ untuk menyerap sebagian besar cahaya datang dibandingkan dengan kristal silikon yang membutuhkan film setebal $50 \mu \mathrm{m}$. Ini karena koefisien aborpsi silikon amorf 10 kali lebih tinggi dari pada kristal silikon. Biaya produksi silikon amorf (a-Si) lebih rendah dari pada kristal

*E-MAIL: sidopekso61@yahoo.com.au silikon (c-Si). Celah pila terlarang untuk a-Si sekitar 1,6 eV sementara c-Si 1,1 eV, karenanya a-Si lebih cocok untuk spektrum matahari.

Persyaratan energi dalam pembuatan solar a-Si jauh lebih kecil dari pada $\mathrm{c}-\mathrm{Si}$, dengan mengacu kepada temperatur pertumbuhan terendah $200-400^{\circ} \mathrm{C}$ untuk a-Si dan $1200^{\circ} \mathrm{C}$ untuk c-Si. Dapat disimpan pada substrat yang tidak mahal seperti kaca atau logam. a-Si berpotensi untuk membentuk multi sambungan yang akan mengarahkan pada peningkatan efisiensi. Pada mulanya pembuatan materi silikon amorf tidak berhasil dideposit, sebagai hasilnya materi memiliki kerapatan keadaan pita yang sangat tinggi, penyelidikan terus berlanjut sampai 1969 ketika sekelompok ilmuan menggunakan pengosongan sinar, desis frekwensi radio untuk menghasilkan silikon amorf dan silane, hailnya adalah tingkat Fermi tergeser ke dalam celah dan mengurangi kerapatan daerah celah terbatas. Daerah celah dalam a-Si berhubungan dengan untai ikatan pada silikon dan pengikatan dengan hydrogenated akan menguranginya. Penelitian tentang silikon amorf hydrogenated masih terus berlangsung dengan tujuan mengurangi biaya pembuatan dan meningkatkan efisiensi.

\section{Metode Pembuatan Lapisan a-Si :H}

Terdapat beberapa metode penyimpanan a-Si:H seperti pengosongan sinar, desis frekwensi radio dan pengendapan uap kimia (Chemical Vapour Deposition, CVD). Setiap metode mempunyai keuntungan dan kerugian masingmasing. Diantara yang lain dengan CVD dibagi menjadi CVD bertekanan rendah, CVD homogen dan CVD bertekanan atmosfer. Penelitan tentang CVD atmosfer telah berlangsung bertahun-tahun di Murdoch University [1, 2]. Pada dasarnya, CVD bertekanan atmosfer adalah proses pelapisan polysilane silikon amorf hydrogenated.

Dengan melewatkan arus gas yang mengandung silane yang lebih tinggi. Metoda APCVD (Atmospheric pressure CVD method, APCVS) dikembangkan di Murdoch University dengan mengikuti teknik Ellis dan Gordon. 


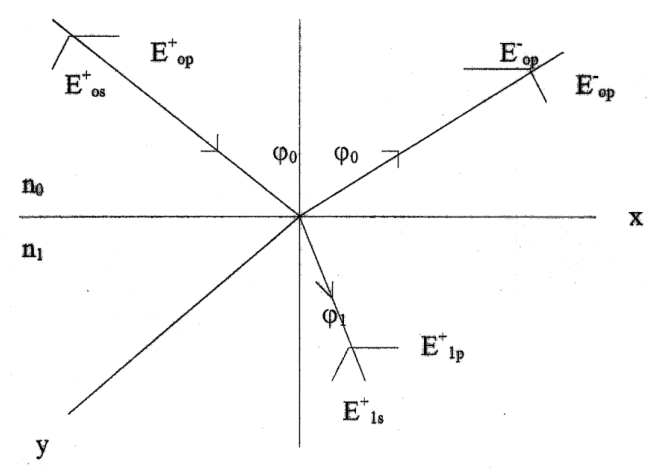

Gambar 1: Pemantulan dan pembiasan

\section{PEMBAHASAN}

Pada kasus dimana lapisan tipis dilapisi di atas plat baja tipis maka metode pemantulan cahaya adalah satu-satunya alternatif yang dapat dilakukan untuk mendapatkan informasi tentang lapisan tipis tersebut. Ketebatalan dan index bias dapat diperoleh dengan metode pemantulan yang menggunakan ellipsometer. Untuk memahami metode pemantulan pertama perlu dipahami prinsip dasar dari persamaan cahaya untuk satu lapisan kemudian dilanjutkan dengan pemantulannya dari lapisan film tipis diatas lapisan plat baja.

Ketika cahaya jatuh di atas sebuah permukaan dengan amplitudo dari faktor elektriknya diberikan $\mathrm{E}_{o p}^{+}$dan $\mathrm{E}_{o s}^{+}$dengan p sebagai electric vector parallel dan s sebagai electric vector dengan arah tegak lurus terhadap permukaan. Pemantuan dan pembiasan cahaya yang jatuh di atas sebuah permukaan aplitudonya dituliskan sebagai berikut $\mathrm{E}_{o s}, \mathrm{E}_{o p}^{-}$dan $\mathrm{E}_{1 s}^{+}$dengan sudut datang $\varphi_{\circ}$ dan sudut pembiasan $\varphi_{1}$ ditunjukkan pada Gambar 1.

Pada daerah batas, untuk arah x dan y dapat dinyatakan: [3]

$$
\begin{aligned}
& E_{\circ x}=\left(E_{\circ p}^{+}+E_{\circ p}^{-}\right) \cos \left(\theta_{\circ}\right) \\
& E_{\circ y}=E_{\circ s}^{+}+E_{\circ s}^{-} \\
& H_{\circ x}=n_{\circ}\left(E_{\circ s}^{+}+E_{\circ s}^{-}\right) \cos \left(\theta_{\circ}\right) \\
& H_{\circ y}=n_{\circ}\left(E_{\circ s}^{+}+E_{\circ s}^{-}\right)
\end{aligned}
$$

dan pada medium pertama

$$
\begin{aligned}
& E_{1 x}=1 E_{1 p}^{+} \cos \left(\theta_{1}\right) \\
& E_{1 y}=E_{1 s}^{+} \\
& H_{1 x}=-n_{1} E_{1 s}^{+} \cos \left(\theta_{\circ}\right) \\
& H_{1 y}=n_{1} H_{1 p}^{+}
\end{aligned}
$$

Untuk mendapatkan amplitudo vektor tertransmisi dan vektor terpantul dalam suku vektor sinar datang, syarat batas digu- nakan

$$
\begin{aligned}
& \frac{E_{\circ p^{+}}}{E_{\circ p^{-}}}=\frac{n_{\circ} \cos \theta_{1}-n_{1} \cos \theta_{\circ}}{n_{\circ} \cos \theta_{1}+n_{1} \cos \theta_{\circ}}=r_{1 p} \\
& \frac{E_{\circ s^{+}}}{E_{\circ s^{-}}}=\frac{2 n_{\circ} \cos \theta_{\circ}}{n_{\circ} \cos \theta_{\circ}+n_{1} \cos \theta_{1}}=t_{1 p} \\
& \frac{E_{\circ s^{-}}}{E_{\circ p^{+}}}=\frac{n_{\circ} \cos \theta_{\circ}-n_{1} \cos \theta_{1}}{n_{\circ} \cos \theta_{\circ}+n_{1} \cos \theta_{1}}=r_{1 s} \\
& \frac{E_{1 s^{+}}}{E_{\circ s^{+}}}=\frac{2 n_{\circ} \cos \theta_{\circ}}{n_{\circ} \cos \theta_{1}+n_{1} \cos \theta_{1}}=t_{1 s}
\end{aligned}
$$

dengan $\mathbf{r}_{1 p}$ dan $\mathbf{r}_{1 s}=$ koefisien pemantulan Fresnel, $\mathbf{t}_{1 p}$ dan $\mathbf{t}_{1 s}$ $=$ koefisien transmisi Fresnel.

Reflektan (perbandingan energy terpantul atau energy yang ditransmisikan) untuk cahaya pada normal sinar datang pada medium isotropic koefisien refleksi dinyatakan dalam suku index bias

$$
R_{p}=R_{s}=\left(\frac{n_{\circ}-n_{1}}{n_{\circ}+n_{1}}\right)^{2}
$$

Koefisien refleksi $\mathrm{R}_{p}=\mathrm{R}_{s}$ dapat dinyatakan dalam suku koefisien Fresnel $r_{x}^{2}$, dengan $\mathrm{x}$ tergantung pada film pada permukaan, kita hanya menggunakan tiga nilai. $r_{\circ}^{2}$ untuk koefisien refleksi antara udara dan sampel, $\mathrm{r}_{1}^{2}$ untuk koefisien refleksi antara udara dan film, $\mathrm{r}_{2}^{2}$ untuk koefisien refleksi antara film dan sampel.

\section{EKSPERIMEN}

\section{A. Preparasi sampel}

Prosedur penyiapan stainless steel telah dikembangkan oleh S Phillip lebih dari 18 bulan dan telah dijelaskan sebelumnya (S.Phillip 1986). Untuk persiapan substrat kita adopsi prosedur berikut ini.

Mula-mula sempel metal disemir menggunakakain dan perekat intan berderajat 1-3 $\mu \mathrm{m}$. diikuti dengan derajat 0-1 $\mu \mathrm{m}$ sampai tidak ada goresan yang tampak, lalu ikuti langkahlangkah berikut ini: (1). basuh dalam air ultra-murni, (2). panaskan beberapa jam pada piala atau isopopanol AR, (3). basuh dalam isopropanol dan bersihkan dalam bak ultra sonic selama 15 menit, (4). basuh dalam air ultra-murni, (5). dipahat (etching)dengan $\mathrm{HF} / \mathrm{NO}_{3}$ dengan perbandingan campuran $1: 9$, (6). basuh dalam air ultra-murni, (7). basuh dalam isopropanol AR, (8). basuh lagi dalam air ultra-murni, (9). keringkan dengan aliran gas $\mathrm{N}_{2},(10)$. diamkan pada dessicator udara kering selama 12 jam.

Substrat stainless steel yang bersih kini telah siap untuk diukur.

\section{B. Pengukuran pemantulan}

Permukaan yang memantulkan dengan tinggi untuk kalibrasi latar belakang (back ground) FTIR dibuat dengan menyimpan alumunium pada slide mikroskop, dengan bantuan Dr. 


\begin{tabular}{|c|c|c|}
\hline Sample & $\mathbf{R}_{\max } / \mathbf{R}_{\min }$ & Index Bias \\
\hline M419 & 2,1 & 3,4 \\
\hline M418 & 2,079 & 3,5 \\
\hline M416 & 2,369 & 3,3 \\
\hline M428 & 2,983 & 3,1 \\
\hline M445 & 3,562 & 2,9 \\
\hline M426 & 2,843 & 3,1 \\
\hline M441 & 3,618 & 2,9 \\
\hline M443 & 2,653 & 3,2 \\
\hline M442 & 2,5 & 3,2 \\
\hline M453 & 2,2 & 3,3 \\
\hline M420 & 2,6 & 3,2 \\
\hline M439 & 2,195 & 3,4 \\
\hline M449 & 2,73 & 3,1 \\
\hline
\end{tabular}

J C Cornish, menggunakan sistem vakum pada orde tekanan $10^{-5}-10^{-7}$ torr. Alumunium diuapkan dari putaran gulungan aluminium murni pada filament tungsten yang dapat menghambat panas.

Sistem pembeslahan pemantulan yang kita gunakan dengan menggunakan dua buah cermin. Dalam sistem ini cahaya tidak secara langsung ditransmisikan menuju sampel. Anggap cahaya datang dari sumber, mula-mula cahaya dipantulkan oleh cermin pertama kemudian dipantulkan oleh cermin kedua pada sempel. Akhirnya pemantulan ketiga dari cermin terakhir mengembalikan arah berkas kearah semula sebelum dideteksi oleh detektor.

Sistem ini berdampak mengurangi intensitas cahaya datang untuk pengukuran background. Oleh karena itu kita menggunakan yang masih segar dengan menyimpan kaca aluminium pada posisi sampel. Kami percaya ia akan memantulkan cahaya lebih baik dari $90 \%$. [2]

Aluminium tadi di-scan dengan menggunakan FTRIR 1720-X dalam jangkah $5000-370 \mathrm{~cm}^{-1}$ dan menyimpan hasil scannya sebagai background, kemudian mengganti kaca aluminium dengan substrat logam yang tidak tertutup, hasil scannya sebagai sampel acuan. Akhirnya scan sampel logam yang sudah disimpan film a-Si dikurangkan scan dari sampel acuan, spectrum yang diperoleh untuk sampel M420.

Dengan mengambil nilai $\mathrm{R}_{\max } / \mathrm{R}_{\min }$ dari spektrum, nilai index bias didapatkan 3,2 pada panjang gelombang $\lambda=2197$ $\mathrm{nm}$ dengan kesalahan $\mathrm{R}_{\max }=18,4 \mathrm{E}_{r}=0,272 \%, \mathrm{R}_{\min }=47,9$
$\mathrm{E}_{r}=0,104 \%, \Sigma \mathrm{E}_{r}=0,376 \%$, sehingga nilai index bias 3,2 $\pm 0,0012$.

\section{HASIL}

Hasil pengukuran indeks bias sejumlah sampel diperoleh data seperti ditunjukkan pada Tabel 1 (pengukuran dilakukan dalam spektrum infra merah (IR)).

\section{SIMPULAN}

Dari eksperimen kita dapatkan nilai index bias yang ditentukan pada daerah IR $5000-370 \mathrm{~cm}^{-1}$ seperti terlihat pada table yaitu 3,2. Dengan menggunakan metode refleksi kita memperoleh hasil yang baik yang mendekati persamaan Goodman untuk pengukuran transmisi. Lalu metode substraksi (pengurangan), mengurangi sinyal terhadap subtract. Ini akan sama dengan spectrometer dengan dua berkas. Oleh karena itu metode ini valid untuk perhitungan index bias film a-Si:H pada substrat logam dengan index bias kompleks. Nilai indeks bias yang kita peroleh sama dengan yang diperoleh S.Philip [8].

- Sampel lama yang kita gunakan sudah terkontaminasi dalam atmosfir, dan permukaan tidak datar dan halus karena adanya goresan. Ini akan mengakibatkan cahaya pantul menyebar tidak memfokus.

- Kontaminasi dengan material lain seperti karbon dan oksigen selama penyimpanan. Alasan utama perbedaan ini adalah karena adanya perbedaan panjang gelombang dimana index bias diukur. Sudah ditenggarai bahwa index bias tergantung pada panjang gelombang, panjang gelombang bertambah akan mengakibatkan pengurangan index bias.

Pengembangan teknik yang berguna dalam pengukuran indek bias dan meningkatnya pada spectrum IR agar dapat menentukan kandungan hidrogennya. Ini mempunyai aplikasi yang luas dalam pencirian film tipis khususnya film a-Si untuk terapan energy solar sel.
[1] Research Report, Murdoch University, (1988)

[2] Clare B W. Cornish J C L, Hefter G T, Jenning P J, Lund C P, Philips S R Raika G, Research Report, Murdoch University.

[3] Heaven O S, Optical Properties of Thin Solid Films (Butter Worths Scientific Publications, London, 1955 ).

[4] Goodman A M, J Appl Opt. 27, 2779-2787 (1978).

[5] Acevendo A.M, Solar Cells. 14, 43-49 (1985).

[6] Ohlidai I and Navratil K, Thin Solid Film, 156, 181-189 (1988).
[7] Olsen D E, Modern Optical Methods of Analysis (Mc Graw Hill Book Company, United States of Amarica, 1975).

[8] Philips S R, Honour in Physics Thesis, Murdoch University, 1986

[9] Swanepoel R, J.Sci.Tech., 16,1214-1222 (1983).

[10] Vasicek A, Optics of thin Films (North-Holland Publishing Company, Amsterdam, 1960). 